\title{
HADTUDOMÁNYI SZEMLE
}

DOI: $10.32563 /$ hsz.2019.1.ksz.16

2019. XII. évf. Különszám

\section{POHL ÁRPÁD 1}

\section{A magyar tisztképzés előtt álló kihívások}

\section{Challenges of the Hungarian Officer Education}

\section{Absztrakt}

A Zrínyi 2026 Honvédelmi és Haderőfejlesztési Programról már nagyon sok szó esett, azonban az elmúlt hetekben kerültek nyilvánosságra olyan részletek, amelyek alapján a katonai felsőoktatás is meg tudja kezdeni a felkészülést. $A$ változások a Magyar Honvédség egészét érintik, és messze túlmutatnak az új haditechnikai eszközök alkalmazásának elsajátításán. Magától értetődik, hogy oktatás nélkül a tervezett átalakítás nem vihető sikerre, ezért a Nemzeti Közszolgálati Egyetem Hadtudományi és Honvédtisztképző Karának is haladéktalanul meg kell kezdenie a felkészülést. Az írásomban olyan gondolatokat, irányokat vázolok, amelyek mentén megindulhat a katonai felsőoktatás új kihívásokra történő felkészítése.

Kulcsszavak: tisztképzés, haderőfejlesztés, felkészités, kihívás

\section{Abstract}

There has been a lot of talk about the Zrínyi 2026 Defence and Military Forces Development Program, and in recent weeks, details have been publicised that will allow military higher education to start its preparation. The challenges will have an impact on the entire Hungarian Defence Forces and go far beyond learning the use of new military technology and equipment. It goes without saying, however, that without training and education, the planned transformation cannot be accomplished successfully, therefore the National University of Public Service Faculty of Military Science and Officer Training must immediately start preparing for it. In my study, I outline some thoughts and guidelines along which the preparation of military higher education for such challenges can begin.

Keywords: officer training, forces development, preparation, challenge

\footnotetext{
${ }^{1}$ Nemzeti Közszolgálati Egyetem Hadtudományi és Honvédtisztképző Kar; dékán, E-mail: pohl.arpad@uni-nke.hu, ORCID: https://orcid.org/0000-0003-3768-4293
} 


\section{HADTUDOMÁNYI SZEMLE}

DOI: $10.32563 /$ hsz.2019.1.ksz.16

2019. XII. évf. Különszám

\section{BEVEZETÉS}

A Magyar Honvédség jelenleg egy régóta nem látott, ugyanakkor nagyon várt fejlesztési folyamaton megy keresztül. A változások fö indikátora a kialakult új világrend, ami számtalan közvetett és közvetlen veszélyt is jelent Magyarország számára. Az új kihívások zömükben olyanok, amelyekkel korábban nem találkoztunk, illetve egyértelművé vált, hogy vissza kell térni a missziós tevékenység túlsúlyától a klasszikus országvédelmi feladatokhoz. A tömeges migráció okozta válsághelyzetben a katonai erő alkalmazása új feladatrendszert hozott a Magyar Honvédség számára. Egy ilyen, a rendőrség munkáját korábban soha nem látott mértékben támogató tevékenység villámgyors reagálást követelt, ami magában foglalta az erők felkészítését, átcsoportosítását, a feladatok végrehajtása logisztikai hátterének létrehozását és a vezetési rend kialakítását. Számos tapasztalatot lehetett szerezni, azonban ez a feladat nem egy klasszikus országvédelmi helyzetre válaszolt.

A biztonsági környezet átalakulása alapvetően megváltoztatta a NATO közös védelmének súlypontjait. Ismét előkerültek a hidegháború idejéből ismert fogalmak, mint az elrettentés (deterrence) és az ellenálló képesség (resilience). A nemzetközi gyakorlatok témái között újra megjelent a jelentős erők fogadása, állomásoztatása és továbbmozgatása (RSOM: Reception Staging Onward Movement). A logisztikusoknál elötérbe kerültek a Befogadó Nemzeti Támogatás (BNT, HNS: Host Nation Support) témakörei. Évtizedek óta nem látott külföldi csapatmozgás volt hazánkban, amelynek a kezelése és támogatása új kihívásokat jelentett.

A fentiekből következik, hogy a NATO-tagállamok több olyan döntést hoztak, amelyek a haderők fokozott fejlesztését célozzák oly módon, hogy az biztosítsa a klasszikus hadviselési képességek kialakítását. Az európai tagállamok az elmúlt három évtizedben folyamatosan számolták fel nehézfegyverzetű csapataikat, és főleg a béketámogató műveletekre koncentráltak. Ez a helyzet nem volt tovább tartható, ezért valamennyi tagállamban megtörtént a védelmi költségvetések emelése és a korábbi képességek visszaépítése. Ennek mértéke ugyan a geopolitikai helyzettől függően differenciáltan valósul meg, azonban a tendencia általánosnak mondható. Természetesen a keleti fenyegetésre másként reagálnak a Szövetség keleti peremén elhelyezkedő tagállamok, mint a nyugati országok.

Magyarország kormánya szintén történelmi léptékü fejlesztés mellett döntött. A Zrínyi 2026 Honvédelmi és Haderőfejlesztési Program közvetlen választ jelent a biztonsági kihívásokra. A magyar célok között is ott szerepel a GDP $2 \%$-át elérő védelmi költségvetés, továbbá megkezdődött a honvédség teljes modernizációja. A mára ismertté vált információk alapján a magyar haderő olyan csúcstechnológiájú haditechnikai eszközökhöz fog jutni, amelyek hadrendbe állítása után valóban a Magyar Honvédség lesz a térség legütőképesebb hadereje.

A modernizáció kulcsszereplője azonban nem a haditechnika, hanem az ember. Kimüvelt emberfők nélkül egy ilyen átalakítást nem lehet végrehajtani, ezért kijelenthető, hogy a katonai felsőoktatás az egész folyamat stratégiai szereplője kell, hogy legyen. A fejlesztéshez kapcsolódó felkészítések azonban nem csupán a haditechnikai eszközökre koncent- 


\section{HADTUDOMÁNYI SZEMLE}

DOI: $10.32563 /$ hsz.2019.1.ksz.16

2019. XII. évf. Különszám

rálnak, hanem a hadikultúra teljes átalakítására. Az új hadfelszerelés megkívánja a doktrínális, az alkalmazási és az üzemfenntartási elvek átdolgozását. Ezek a folyamatok be kell, hogy épüljenek a tiszt- és altisztképzés rendszerébe, ezért írásomban a rendelkezésemre álló információk alapján azoknak az új kihívásoknak a beazonosítására teszek kísérletet, amelyek meghatározzák a tisztképzés fejlesztésének irányait.

\section{A KATONAI FELSŐOKTATÁS HELYZETE}

A katonai felsőoktatás 2011-ben alapvető változásokon ment át. A Zrínyi Miklós Nemzetvédelmi Egyetem megszünt, és a tisztképzés egykaros szervezetben integrálódott a Nemzeti Közszolgálati Egyetembe (továbbiakban: NKE). A 2012. január 1-jén alakult új egyetem egy meglepő, de azóta a világ számos országában elismert modellt valósított meg: egyesítette a közszolgálati hivatásrendeket, és közös értékek, a Magyar Királyi Honvéd Ludovika Akadémia alapjaiból építkezve teljesíti küldetését: „A magyar felsőoktatási rendszer részeként a közigazgatási, rendészeti és katonai képzést folytató Nemzeti Közszolgálati Egyetem tevékenységének célja a közigazgatást, a hon- és rendvédelmet érintő tevékenységet végző szakemberek képzése, a hon- és rendvédelmi szervek tiszti utánpótlásának biztosítása, valamint az egységesülő közszolgálati életpályák közti átjárhatóság megteremtése."2

A Honvédelmi Minisztérium és a Magyar Honvédség akkori vezetői új alapokra helyezték a tisztképzést. Alapvető követelményként jelentkezett a vezetői, alegység-parancsnoki felkészítés előtérbe helyezése. A mérnök- és a közgazdászképzés pótlására a polgári egyetemekről toborzandó szakemberekböl került volna sor. Akkor még nem látszott, hogy ez a koncepció a magyar munkaerőpiacon nem működőképes.

Bizonyos fegyvernemek és szakcsapatok ellehetetlenüléséhez vezetett volna, ha a szakfelelősök végrehajtják a 3+1 éves képzési modellt. Egyértelmű volt, hogy egy évbe nem lehet a szakmai felkészítést besűríteni.

A fenti elgondolások mellett erőteljesen lecsökkent az a rendelkezésre álló idő, amit az első tiszti beosztásra történő felkészítésre lehetett fordítani. Követelményként fogalmazódott meg, hogy az alapkiképzés kerüljön be a tantervbe, ami csaknem egy egész félévet lefoglalt. Az NKE küldetéséből adódóan az Egyetemi Közös Modul (továbbiakban: EKM) megjelent a katonai felsőoktatás alapképzési szakjainak tantervében, így már egy második félév hiányzott a konkrét katonai képzésből. Itt azonban meg kell állapítani, hogy az EKM elgondolása teljes mértékben összhangban volt az NKE fenntartóinak szándékával. Mára azonban bebizonyosodott, hogy a Közös Közszolgálati Gyakorlaton kívül az EKM kurzusai az erőfeszítések ellenére nem hozták közelebb egymáshoz a különböző karok hallgatóit, ezért a dékánok megkezdték a teljes koncepció átdolgozását. A szakok alapozására tehát

\footnotetext{
${ }^{2}$ 2011. évi CXXXII. törvény a Nemzeti Közszolgálati Egyetemröl, valamint a közigazgatási, rendészeti és katonai felsőoktatásról. https://net.jogtar.hu/jogszabaly?docid=A1100132.TV (A letöltés ideje: 2019. 02. 03.)
} 


\section{HADTUDOMÁNYI SZEMLE}

DOI: $10.32563 /$ hsz.2019.1.ksz.16

2019. XII. évf. Különszám

csak két szemeszter áll rendelkezésre, ami számos területen - föleg ahol bonyolult haditechnikával kell dolgozni - nem elegendő.

A specializációra helyezés időpontjának másodév végére történő elörehozása már lényegesen nagyobb mozgásteret engedett a konkrét szakmai képzésnek, mert a négy szemeszternyi idő egyértelmüen biztosítja az első tiszti beosztáshoz szükséges szakmai ismeretek megszerzését. Az egyetemi tisztképzés számára további korlátozást jelentett, hogy a tiszti felkészítés általános katonai részében megjelent egy nem felsőoktatási szereplő, az MH Ludovika Zászlóalj. A zászlóalj kiképzési programja alapján hetente két délután áll rendelkezésükre úgynevezett szocializációs foglalkozások megtartására, továbbá félévente egy hét kihelyezés általános katonai felkészítésre. Ezek a feladatok természetesen a szakmai felkészítés időkeretét is befolyásolták. Jelen írásomban nem vállalkozom ezen kettősség elemzésére, de az elmúlt évek tapasztalatai alapján halaszthatatlanná vált ennek a modellnek a felülvizsgálata. A tisztképzés átalakítására ható tényezőket az 1 . számú ábra szemlélteti.

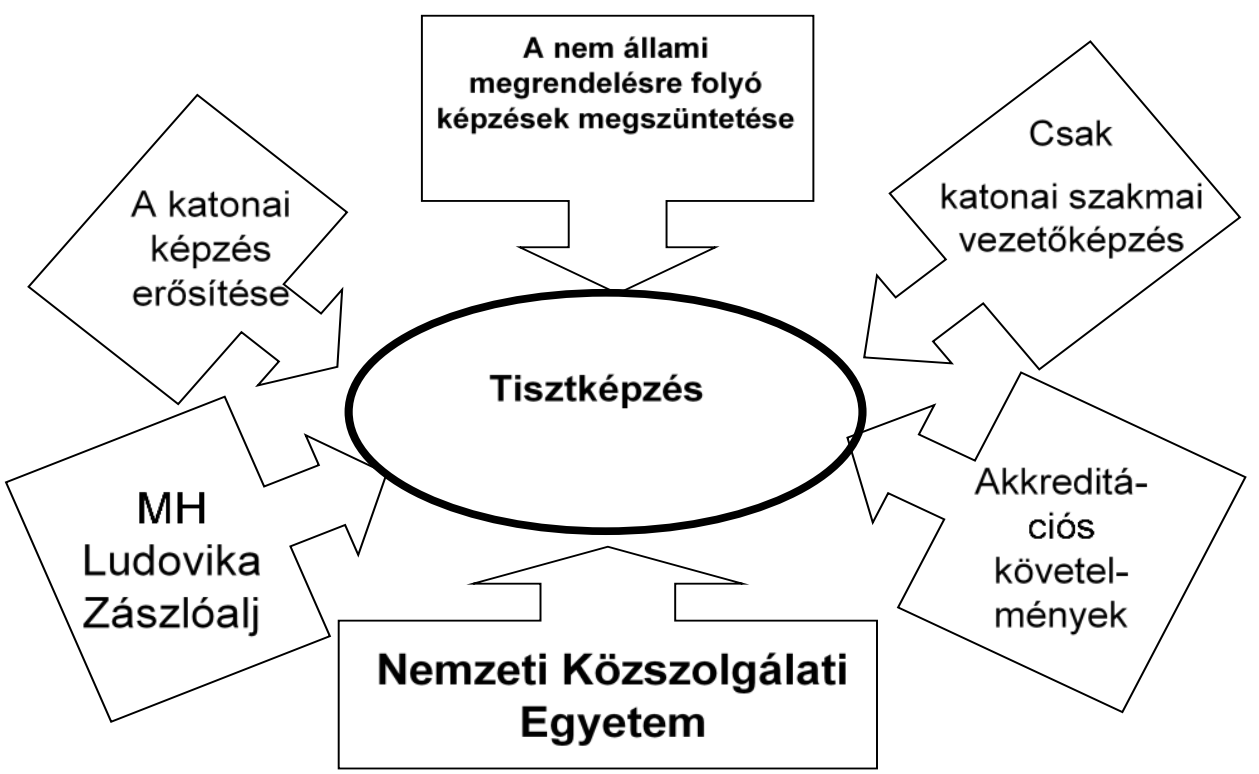

1. ábra: Az új tisztképzés környezete ${ }^{3}$

(Forrás: saját szerkesztés)

${ }^{3}$ Pohl Árpád: Az új rendszerü logisztikai tisztképzés - valóban „eltűnt” a szakma? Hadmérnök, 10 (2015/1). 53. 


\section{HADTUDOMÁNYI SZEMLE}

DOI: $10.32563 /$ hsz.2019.1.ksz.16

2019. XII. évf. Különszám

Az ábra alapján megállapítható, hogy a tisztképzés átalakítására alapvető hatást gyakorolt a költségtérítéses képzések megszűnése és a katonai felkészítés erősítése. A korábbiakhoz képest további változást jelentett, hogy a korábbi mérnök és közgazdász szakon is át kellett térni az alegység-parancsnoki, vezetői képzésre. Ez a folyamat nem volt egyszerü, mert az oktatók szerettek volna ragaszkodni a korábbi szakmai színvonalhoz, azonban ezt csak a katonai szakmai ismeretek körében sikerült megőrizni.

A szakok vezetőinek minden erőfeszítése arra irányult, hogy a programok szakmai tartalma lehetőleg minél kevesebbet csökkenjen. Az egész katonai felsőoktatás fellélegzett, amikor a specializációra helyezést hivatalosan is sikerült a negyedik félévre elöre hozni. Ennek köszönhetően a szűk szakmai képzésre négy szemeszter jutott, ami elegendő volt az első tiszti beosztásra történő felkészítéshez. Az oktatói kar jelentős része nyugállományú tisztekből állt, ezért a nyugdíjasok foglalkoztatása jogszabályi kereteinek váratlan változása alapvető működési zavarokat okozott. A tisztképzés tehát éppen befejezte az átalakítást, és az első évfolyam avatására került sor 2016-ban, amikor bejelentették a Zrínyi 2026 Honvédelmi és Haderőfejlesztési Programot. Tisztán látszott, hogy nem egy megszokott haderőreformról van szó, amely további csökkentést jelent. Egy történelmi lehetőséget kaptak a katonák, hogy létrehozzák a 21. század Magyar Honvédségét. Sajnos az indokolt szigorú titoktartás miatt a tisztképzéshez szükséges információkra 2018-ig várni kellett, azonban 2019 elején már intenzíven megindulhatott a külföldi képzések, továbbképzések előkészítése.

\section{A MODERNIZÁCIÓ HATÁSA A KATONAI FELSŐOKTATÁSRA}

A Zrínyi 2026 Honvédelmi és Haderőfejlesztési Program a katonai felsőoktatás számára is új kihívást és egyben történelmi lehetőséget jelent. A haderő fejlesztése a haditechnikai modernizáción messze túlmutató átalakítást tesz szükségessé. Az új haditechnikai eszközök új alkalmazási elveket, új üzemeltetési és üzemfenntartási stratégiákat, valamint kiválóan felkészített alkalmazói és üzembentartó állományt igényelnek. A változások érintik a teljes Magyar Honvédséget. Joggal tehető fel a kérdés, hogy nincs-e késésben a tisztképzés? A Magyar Honvédség Parancsnokságának megalakulásával 2019. január 1-től jöttek létre azok a vezető szervek, amelyek a Zrínyi 2026 megvalósításáért felelnek. A Szemlélőség, mint szervezeti elem megjelenése a tisztképzéshez szükséges együttműködési rendszer újra gondolását követeli meg. Egy új, a fejlesztési folyamatok menedzseléséért felelős szervezeti egység jött létre a Parancsnokságon belül: az MH Modernizációs Intézet. Ennek pontos feladatrendszere még nem ismert, de a honvédségi $\mathrm{K}+\mathrm{F}+\mathrm{I}$ folyamatokban biztosan kulcsszerepet fog játszani. A szervezeti változások velejárója lesz a kezdeti bizonytalanság, az útkeresés és az ügyintézés nehézkessége. A partnerek beazonosítása után ezek a problémák várhatóan megszűnnek, de ez a HHK szervezeti egységeinek vezetőitől kiemelt odafigyelést fog igényelni.

A Magyar Honvédség egy több mint fél évszázados technológiai ugrást hajt végre. A 60-as évek haditechnikai színvonaláról közbülső lépcsők nélkül történik az átlépés a 21 . század második negyedébe. A korábbi években - néhány terület kivételével - a katonák 


\section{HADTUDOMÁNYI SZEMLE}

DOI: $10.32563 /$ hsz.2019.1.ksz.16

2019. XII. évf. Különszám

csak azzal foglalkoztak, hogyan lehetne a folyamatosan romló körülmények közepette fenntartani az alaprendeltetésnek való megfelelést. A polgári életben látható fejlődéshez képest a haditechnika fejlettsége stagnált, és olyan képet mutatott, ami egyáltalán nem növelte a katonák önbizalmát és a társadalom honvédség iránti bizalmát.

A katonai felsőoktatás jelenleg négy alapképzési (Katonai vezető, Katonai üzemeltető, Katonai logisztika, Állami légiközlekedési) és négy mesterképzési szakból (Katonai vezető, Katonai üzemeltető, Katonai műveleti logisztika, Védelmi infokommunikációs rendszertervező) áll, amelyhez még szervesen illeszkednek a Hadtudományi Doktori Iskola és a Katonai Müszaki Doktori Iskola kurzusai. Ebből is látható, hogy jelenleg még ott vagyunk a többciklusú lineáris képzés minden szintjén, ami nagy érték. Sajnálatos módon annak ellenére, hogy a nyugati tisztképzések jelentős része a társadalmi és jogi elismertségért küzd, újra és újra felbukkannak olyan gondolatok, amelyek megkérdőjelezik a katonai felsőoktatás szükségességét.

A 211 éves múltra visszatekintő magyar katonai felsőoktatás előtt álló legfontosabb kihívások a következők:

- az oktatói állomány kedvezőtlen korfája;

- a Zrínyi 2026-ból következő haditechnikai korszakos fejlesztés;

- az oktatók átképzése;

- a honvéd tisztjelöltek hazai és külföldi képzése, gyakoroltatása;

- német és francia nyelvképzés;

- a haditechnika oktatásának még nem ismert feltételei;

- a tanterv szükséges átalakítása.

A HHK oktatói korfája nem kiegyensúlyozott, néhány területen kifejezetten kedvezőtlen. Jelenleg már olyan kulcsfontosságú fegyvernemek tisztképzésében, mint a tüzér vagy a harckocsizó nincs tudományos fokozattal rendelkező egyetemi oktató, ami alapjaiban megkérdőjelezi a Kutatás-Fejlesztés-Innováció (KFI) terén jelentkező kihívások kezelését. A HHK egy munkacsoportja ${ }^{4}$ 2018-ban elemezte a kialakult helyzetet. A következő ábra a 49,1 éves átlagéletkorral rendelkező oktatói állomány kor szerinti összetételét szemlélteti.

\begin{tabular}{|c|c|c|}
\hline \multicolumn{3}{|c|}{ Oktatói korfa } \\
\hline életkor & fö & $\%$ \\
\hline $60-69$ & 13 & 13 \\
\hline $50-59$ & 37 & 38 \\
\hline $40-49$ & 31 & 32 \\
\hline $30-39$ & 16 & 16 \\
\hline $20-29$ & 1 & 1 \\
\hline
\end{tabular}

1. táblázat: A HHK oktatói korfája (Forrás: a HHK munkacsoport jelentése)

\footnotetext{
${ }^{4}$ Dr. habil. Jobbágy Zoltán ezredes, tudományos és nemzetközi dékánhelyettes, Ináncsi Andrea őrnagy, személyügyi fötiszt és Stummer Judit főmunkatárs.
} 


\section{HADTUDOMÁNYI SZEMLE}

DOI: $10.32563 /$ hsz.2019.1.ksz.16

2019. XII. évf. Különszám

A fenti táblázat adataiból jól látszik, hogy az oktatói utánpótlás érdekében haladéktalanul lépni kell. A megoldás a csapatoknál és a vezető szerveknél meglévő krónikus tiszthiány miatt komoly nehézségekbe ütközik. A HHK munkacsoportja azt is megvizsgálta, hogy 2018-2027. között az egyetemi tanárok 88\%-a, a habilitált docensek 67\%-a és a docensek 57\%-a fogja elhagyni a felsőoktatást. Az elmúlt évek tapasztalatai azt mutatják, hogy a 60. életévüket betöltött oktatók is elmennek, függetlenül az oktatói fokozattól (pl. egy fő egyetemi tanár a 70. életévig terjedő munkaviszony lehetőségének ellenére 60 évesen nyugállományba vonult). A helyzet megoldására több lehetőség kínálkozik. A legfontosabb, hogy a pontos elömeneteli követelményekkel, szabályozott mérési pontokkal rendelkező oktatói karriert vonzóvá kell tenni. Éppen ezért lenne fontos a fiatal, pályakezdő tisztek egy részének egyetemen tartása oly módon, hogy a felsőoktatási munka mellett meglegyenek az előmenetelhez szükséges minimum egyéves csapatszolgálatok vagy missziók. Különösen fontos lenne az oktatói beosztásban lévő fiataloknál felmentést adni a mesterszakok századosi bemeneti követelménye alól. Jelenleg az a helyzet, hogy a fiatal oktatók inkább egy másik egyetemen szereznek mesterdiplomát, csakhogy minél előbb megkezdhessék doktori tanulmányaikat. Ezzel a rendszerrel csak konzerváljuk azt a helyzetet, hogy az oktatók jelentős részének nincs katonai mesterszakon szerzett végzettsége.

Az oktatói utánpótlás biztosításának klasszikus és leghatékonyabb utánpótlási forrása a doktori képzés. A HM évente tíz fő levelező és egy fő nappali doktori képzését támogatja. Mindenképpen fontos lenne az MH számára is fontos témák kutatása érdekében növelni a nappali doktoranduszok számát. A honvédség nem tekinthet el attól, hogy saját maga nevelje ki leendő tudományos kutatók egy részét, mert e nélkül nem lesz biztositható az a hadtudományi és katonai műszaki tudás, ami a haderőfejlesztés elengedhetetlen feltétele.

Külön meg kell említeni, hogy az oktatói állomány túlnyomó többségének nem adatott meg, hogy külföldön tanuljon. Ebböl következik, hogy kevesen rendelkeznek megfelelö föleg - angol nyelvtudással.

Az oktatói hiány okozta feszültség csökkentése miatt 2014 óta részfoglalkoztatott státuszban is lehet hivatásos tiszteket alkalmazni. Az elgondolás egyértelmüen helyes volt, azonban mára kiderült, hogy a tartós hiányon ez a megoldás csak erősen korlátozottan képes segíteni.

A Zrínyi 2026 egy olyan korszakváltást eredményez, amelyre az oktatói állományt is fel kell készíteni. A 21. századi hadfelszerelés az $\mathrm{MH}$-ban eddig csak néhány területen jelent meg. A '60-as évek technikai színvonala a számos korszerüsítési kísérlet ellenére konzerválta azt a tudást, amivel a jövőbeli müveleti környezetnek nem lehet megfelelni. Az a korábbi müszaki, mérnöki képesség, aminek a bázisán el lehetne indulni, mára csaknem teljes egészében eltűnt. Még az utolsó pillanatban vagyunk, amikor bizonyos területekre még tudunk kapacitásokat reaktiválni, de ehhez nagyon gyorsan kell egyértelmű döntéseket hozni.

Mindkét haderőnem beszerzései olyan eszközöket érintenek, amelyek vagy a világ legjobbjai között vannak, vagy akár a legkorszerübbnek számítanak. A „vasakat” nem elég rendszerbe állítani, azokat gazdaságosan és hatékonyan kell müködtetni. Ez a régi orosz 


\section{HADTUDOMÁNYI SZEMLE}

DOI: $10.32563 /$ hsz.2019.1.ksz.16

2019. XII. évf. Különszám

haditechnikától teljesen eltérö üzemfenntartási stratégiák kidolgozását fogja megkövetelni, amihez kiinduló alap a külföldi tapasztalatok villámgyors megismerése és a magyar viszonyokra történő alkalmazása. A hadiiparnak a jövőben közvetlenebb és napi hatása lesz az üzemben tartásra és a fejlesztésekre. Ehhez az együttmüködéshez olyan katonai szakemberekre van szükség, akik nem alapszakos üzemeltetői mérnöki végzettséggel, hanem a fenntartási rendszerek tervezéséhez, müködtetéséhez szükséges mesterszintü polgári mérnöki végzettséggel rendelkeznek. Tisztázandó kérdés, hogy a csapatok szintjén milyen mélységű karbantartási, javítási feladatok végezhetők el? A jelenleg rendszerben lévő hadfelszerelésnél is találunk az egyes típusok között korszakos különbségeket (pl. Ural vagy Rába $\mathrm{H}$-sorozat). ${ }^{5}$

A katonai felsőoktatásban mindig is megvoltak azok a kutatások és tananyagok, amelyek a haditechnikai fejlesztés elméleti alapjait rögzítették (Ungvár Gyula, Turcsányi Károly és Kende György munkássága). Ezek egy része ma is aktuális, azonban az új helyzethez új kutatásokra és új tananyagokra van szükség. A szemléletváltás természetesen nem csupán a hadfelszerelés korszerüsítésére vonatkozik, hanem magában foglalja a hadügy minden területét. Senki nem gondolja, hogy a generációkat átugró haditechnikai fejlesztés nem kívánja meg a doktrínális és az alkalmazási alapelvek reformját. Az új gondolkodás, a küldetésorientált vezetésre történő áttérés teljes szervezeti kultúraváltást követel, ami nagyon hosszú időt vesz igénybe. Ezt a váltást parancsra és határidőre nem lehet végrehajtani, csupán a szemléletváltást eredményező képzési és kiképzési rendszer átalakításával, ami együtt jár a magyar hagyományok megőrzésével és az új elvek átvételével, de nem másolásával.

A legkorszerübb fegyverrendszerek beszerzésével ismét szükség lesz a szabályzók átdolgozására, amiben a kapacitások függvényében a HHK oktatói és kutatói eddig is részt vettek. A kidolgozásban történő részvétel egyben azt is lehetővé teszi, hogy az oktatásban megjelenjenek a legújabb ismeretek, követelmények, sőt az optimális az lenne, ha megelőznénk a gyakorlatot. Erre a képességek megvannak. Az elmúlt évek fejlesztési projektjei, amiben a HHK is részt vett, számos tapasztalatot és új kutatási lehetőséget adtak. Ezzel hatékonyan és eredményesen éltünk is. A KÖFOP-2.1.2-VEKOP-15-2016-00001 „A jó kormányzást megalapozó közszolgálat-fejlesztés" című projekt keretében a HHK 320 millió $\mathrm{Ft}$ támogatásban részesült. A nyolc kutatócsoport, öt kutatómühely, a 14 doktori, a két posztdoktori, az egy akadémiai doktori és az öt habilitációs pályázatban összesen 113 fő vett részt, közülük jelentős számban hazai és külföldi egyetemek oktatói. A projektek valamennyien eredményesen lezárultak, az eredménytermékek elkészültek. Ez azt mutatja, hogy megvan a katonai felsőoktatásban az kutatási hálózat, amit a jövőben is eredményesen lehet használni.

${ }^{5}$ Cs. Nagy Géza: Egy lehetséges módszer katonai gépjárművek üzemfenntartása költséghatékonyságának fokozására. Hadmérnök, 6 (2011/1). 


\section{HADTUDOMÁNYI SZEMLE}

DOI: $10.32563 /$ hsz.2019.1.ksz.16

2019. XII. évf. Különszám

A kihívások közül kiemelt jelentőségű az oktatói állomány felkészítése. A helyzet valós megítéléséből az következik, hogy az oktatói létszám kívánt szintre növelése és a strukturális problémák megoldása hosszú folyamat lesz. Alapvető fontosságú a megtartó képesség növelése és a más beosztásokba történő áthelyezések megszüntetése. Egy doktorandusz oktatóra a HHK sok éves felkészítést fordított, ami az áthelyezéssel általában szertefoszlik, mert a honvédség szervezeteinél egyetlen olyan tiszti beosztás sincs, ami tudományos fokozathoz kötött.

Az NKE a 2019. évben elindítja a Tisza István Programot, ami jelentős forrást biztosít az egyetemi minőség fejlesztésére. Ennek jelentős része a HHK jóváhagyásra váró terveiben már a Zrínyi 2026-ból adódó minőségi célok elérését szolgálja. Még nem ismertek a honvédségi átképzési programok, de a HHK a saját nemzetközi együttműködési rendszerében már önállóan elkezdte a felkészítés szervezését. Az könnyen belátható, hogy az egyetemi oktatók részére nem elegendőek azok a szakmai felkészítések, amit a csapatok kapnak, ezért szükséges még kiegészítő lehetőségek után nézni. Alapfeltételnek tekinthető, hogy az $\mathrm{MH}$ által szervezett átképzési programokban a fiatal oktatók részt vesznek. Ennek hiányában a HHK nem tud megfelelni a képzési igényeknek, és úgy járunk, mint az egyik kulcsfontosságú képzési területen, ahol most kell egy sokéves lemaradást nagy erőfeszítések árán behozni.

Az oktatási egységek vezetői részére történt feladatszabás a tanszékek szakmai önállóságából indul ki. Innovatívan, az igények és a lehetőségek összehangolásával kell nagyon gyorsan megkezdeni az átképzéseket. Az önállóság egyben teljes felelősséget is jelent. A munka megkezdéséhez az alábbi feladatok végrehajtására van szükség:

- a rendelkezésre álló információk alapján szakterületenként a forráskutatás és a külföldi tapasztalatok összegyüjtése;

- kapcsolatfelvétel a Szemlélőség illetékeseivel;

- $\quad$ az MH honvédelmi szervezeteivel kialakult szoros együttmüködés kiterjesztése az új területekre;

- a külföldi kapcsolatok aktivizálása és új partnerek felkutatása;

- a honvéd tisztjelöltek képzésébe fokozatosan, egyelöre csak figyelemfelhívó jelleggel beépíteni az új ismereteket;

- a Zrínyi 2026-tal összefüggő szakdolgozati, tudományos diákköri és szakkollégiumi témák ajánlása;

- tanszéki tudományos mühelyekben a szakterületre vonatkozó feladatok beazonosítása és beépítése az indítható projektekbe;

- $\quad$ a szaknyelvi képességek gyors ütemű fejlesztése.

A HHK vezetése megkezdte az előkészítő munkát. A több évtizedes kapcsolatnak köszönhetően katonadiplomáciai úton megtörtént a kapcsolatfelvétel a német és az osztrák partnerekkel. Várhatóan már ebben a negyedévben megtörténnek az első kiutazások. A logisztikai szakterületen már adottak a kapcsolatok, de most eljött az ideje, hogy hasonló kooperáció alakuljon ki minden fegyvernem és szakcsapat vonatkozásában. Példaként szükséges megjegyezni, hogy német haditechnikát hozzánk hasonló korszakos ugrással 


\section{HADTUDOMÁNYI SZEMLE}

DOI: $10.32563 /$ hsz.2019.1.ksz.16

2019. XII. évf. Különszám

több környező ország is átvett, így rendkívül hasznos lehet az ő üzemeltetési, üzemben tartási tapasztalataiknak a megismerése.

Természetesen a tisztképzés minden szintjén a legfontosabb tényező maga a hallgató. Első ütemben alapvetően a honvéd tisztjelöltekre kell fókuszálni. Elkerülhetetlenné vált, hogy az átfegyverzésre kerülő csapatok fiatal tisztjei már alapvető külföldi tapasztalatokkal rendelkezzenek. Célunk, hogy néhány éven belül már több olyan évfolyam is legyen az alegységeknél, akik az adott fegyvernem vagy szakcsapat vonatkozásában külföldi szakmai tapasztalatokkal rendelkeznek. Ebben a HHK eddig is élen járt, amit az is mutat, hogy a tavaly avatott 42 hadnagy közül 12 fö külföldön folytatott tanulmányokat (pl. egy félévet az Erasmus Program keretében egy másik ország katonai felsőoktatási intézményében tanultak). A honvéd tisztjelöltek esetében a legfontosabb az érdeklődés ráirányítása arra a történelmi lehetőségre, amit az MH kapott. Ehhez azonban alapjaiban kell megváltoztatni a tisztképzés jelenlegi időbeosztását, új megoldások után kell nézni. A csapatgyakorlatok új rendszerével a honvéd tisztjelöltek már 15 hetet töltenek csapatnál, amihez még hozzájön a Magyar Honvédség Ludovika Zászlóalj által szervezett félévenkénti egyhetes gyakorlati felkészítés. Így már ott tartunk, hogy 22-23 hétre nyúlik az a gyakorlati felkészítési idő, ami még kiegészíti a tantervben szereplö kihelyezéseket, gyakorlati foglalkozásokat. Hosszú évek tapasztalata mondatja velem, hogy a csapatgyakorlatok hatékonysága erősen differenciált. Milyen új lehetőségeket lehet találni?

Talán a legfontosabb, ha megteremtjük a lehetőséget a külföldi tapasztalatszerzéshez. Ehhez az Erasmus Program forrást biztosít, és megkezdődött az érintett végzősök kéthónapos németországi szakmai gyakorlatának előkészítése. Jóváhagyás esetén a csapatok olyan tiszteket fognak kapni, akik már szolgáltak olyan alegységnél, ahol az adott haditechnikai eszközöket alkalmazzák. Néhány év eltelte után csak olyan alegységparancsnokok lesznek az új szárazföldi technikát használók, akik már külföldi tapasztalatokkal rendelkeznek. Ök egészen biztosan könnyebben fogják befogadni mindazt a tudást, amit az új haditechnikai és alkalmazási elvek jelentenek. Elég csak arra gondolni, amit kiképzés-módszertan terén kell majd elsajátítani és meghonosítani. Mindemellett természetesen nem mondunk le a nemzetköziesítésről. Ez nem csupán felsőoktatási követelmény, hanem a müveletek többnemzeti jellege miatt alapvető katonai elvárás is. Továbbra is fenn kívánjuk tartani a jelenleg futó nemzetközi képzési programokat, továbbá nem mondtunk le arról a célról, hogy minden szakon legyen egy nemzetközi gyakorlat.

A nyelvképzés eddig is stratégiai feladat volt, de a beiskolázási létszámok emelkedése megköveteli új utak és megoldások keresését. Ilyen lehet, hogy eltekintünk az angol kizárólagos bemeneti követelményétől, és éppen a haditechnikai fejlesztések miatt megnyitjuk az utat a francia és a német nyelvvizsgával rendelkező középiskolások előtt. Ez nem jelenti azt, hogy lemondunk az angol STANAG 2.2.2.2. szint eléréséről, de ezek a honvéd tisztjelöltek négy év után kellene, hogy megszerezzék ezt a nyelvtudást. Ennek a tantervben is meg kell jelennie.

Sajnos jelenleg nem ismert, hogy a tisztképzés pontosan mit is fog kapni a gyakorlati képzés végrehajtásához. Ez a kérdés messze túlmutat az oktatáson, mivel jelenleg folyik a 


\section{HADTUDOMÁNYI SZEMLE}

DOI: $10.32563 /$ hsz.2019.1.ksz.16

2019. XII. évf. Különszám

HHK Ludovika Egyetemi Campusra (továbbiakban LEC) költözésének vizsgálata. A tervezést alapvetően befolyásolják ezek a hiányzó információk. Amennyiben központilag történik az MH minden szakmai felkészítése, akkor ehhez a katonai felsőoktatásnak is igazodnia kell, ugyanakkor maximálisan figyelembe kell venni az egyetemi képzés időrendjét. Ez a kérdés az együttmüködés egy újabb minőségét fogja megkövetelni. Mindenképpen vizsgálni szükséges, hogy a LEC városi környezete mit képes befogadni, és mit kell esetleg az ócsai gyakorlótéren felépíteni? A tervezésben részt vevő szakemberek felelőssége óriási, ugyanis utólagos korrekcióra nem lesz lehetőség, vagyis a magyar tisztképzés jövője a tét.

A tisztképzés tantervei átdolgozás előtt állnak. Az előzőekben már említett csapatgyakorlatok beépítése meg fog történni. Komoly elörelátást igényel annak beazonosítása, hogy mikor valósul meg a felsőoktatásban a váltás az új haditechnikai eszközökre. Ennek nyilván előbb meg kell történnie, mint a csapatoknál, ugyanis felesleges időtöltés évekig régi eszközöket és eljárásokat oktatni azért, hogy a kezdő hadnagy mindjárt egy többhónapos átképzésen vegyen részt.

Jelenleg az NKE rektorának vezetésével folyik az Egyetemi Közös Modul átalakítása. Sajnos az eddigi tapasztalatok alapján a közszolgálati ismeretek nem nyerték el a diákok tetszését, sőt, néhány területen kifejezetten ellenérzést váltottak ki. Az új tudásanyag várhatóan jobban megnyeri a hallgatók tetszését, és talán sikerül egy kis időt is nyerni a katonai szakmai alapozás számára. Ez annál is inkább fontos, mert a villamos és gépész területen megvan a lehetőség a mesterképzésen történő részvételre, amivel az MH olyan mérnöktiszteket kaphat, akik alapvetően a katonai felsőoktatásból jöttek, de egy civil mesterszak elvégzése után ugyanazon tudással rendelkeznek, mint a többi okleveles mérnök. Ehhez azonban változtatni kell azon az elváráson, hogy minden szakon alegységparancsnoki képzés folyik, és mindenhol a fö feladat a napi élet irányítása és a harcvezetés. A várható tendenciákat látva nagy valószínűséggel részben vissza kell térni ahhoz a szakemberképzéshez, amit 2011 után be kellett fejezni. Mára kiderült, hogy bizonyos területek vonatkozásában a toborzás teljesen hatástalannak bizonyult, és belső képzéssel kell a szakember utánpótlást megoldani. A tantervi lehetőségek tovább bővülnek, ha az alapkiképzés valóban lerövidül öt hétre. Ezzel azt lehetne elérni, hogy a szakmai képzés majdnem egy teljes szemesztert visszakapna.

\section{ÖSSZEFOGLALÁS}

A Magyar Honvédség a modernizáció történelmi lehetőségéhez jutott, ami számos területen, így a tisztképzés minden szintjén új kihívásokat jelent. A magyar katonai felsőoktatás már nem rendelkezik azokkal a képességekkel, amelyek korábban rendelkezésre álltak. $A z$ oktatás személyi és tárgyi feltételei még éppen biztosítják az új szakok működését, amit a három évvel ezelőtti sikeres akkreditáció is bizonyít. Most azonban olyan új kihívásokra kell felkészülnünk, amilyenekkel évtizedek óta nem találkoztunk. A honvédelem fejlesztése ismét reflektorfénybe került, ami optimizmussal töltheti el a személyi állományt. Különösen fontos, hogy maximálisan történjék meg a meglévő nemzetközi kapcsolatrendszer kihasz- 


\section{HADTUDOMÁNYI SZEMLE}

DOI: $10.32563 /$ hsz.2019.1.ksz.16

2019. XII. évf. Különszám

nálása és fejlesztése. Az új képzési feladatok új megoldásokat fognak igényelni. A karon valószínüleg nem lesznek meg a gyakorlati képzés jelenlegi tárgyi feltételei. Egész biztosan szoros együttmüködésre lesz szükség az új kiképző szervezetek és az NKE HHK között.

Az oktatók továbbképzését azonnal meg kell kezdeni részben együtt az $\mathrm{MH}$ programjaival, részben azt kiegészítve. Ez a már kiválasztott fiatal oktatók külföldi tanulmányait fogja jelenteni. Különösen fontos, hogy az új követelmények alapján történjék meg a tisztképzés tanterveinek, a honvéd tisztjelöltek szocializációjának képzési programokhoz igazodó felülvizsgálata. Pontosan meg kell határozni a prioritásokat, és ehhez kell rendelni a hallgatók időbeosztását. A honvéd tisztjelöltek motivációját külföldi szakmai gyakorlatokkal kell növelni. Minden szak vezetésének és minden oktatási egységnek meg kell találnia azokat a feladatokat és megoldásokat, amivel a fiatal generáció szemléletét, motivációját és elkötelezettségét olyan szintre emeljük, ami megfelel az új kihívásoknak.

Tudom, hogy az előttünk álló út nehéz lesz, azonban ne a nehézségeket nézzük, hanem a lehetőségeket. A magyar katonai felsőoktatás képes megfelelni az új helyzetnek, és az is világos, hogy a kiművelt emberfők nélkül ezt a programot nem lehet megvalósítani. Zrínyi Miklós már a Vitéz hadnagy címü müvében leírta: „Sokat vihet végbe egy jó eszes kapitány rossz haddal is, de a rossz jó haddal is semmit."

\section{FELHASZNÁLT IRODALOM}

1. Cs. Nagy Géza: Egy lehetséges módszer katonai gépjármüvek üzemfenntartása költséghatékonyságának fokozására. Hadmérnök, 6 (2011/1). 5-14.

2. Jobbágy Zoltán: Biztonságpolitika, haderöreformok, a humánerőforrás-gazdálkodás katonai pályával összefüggő kérdései. Hadtudomány, 25 (2015), E-különszám, 30-40.

3. Kende György, Seres György: Haditechnikai kutatás-fejlesztés. Egyetemi jegyzet, Zrínyi Miklós Nemzetvédelmi Egyetem, Vezetés- és Szervezéstudományi Kar Haditechnikai és Minőségügyi Tanszék, Budapest, 2004.

4. Pohl Árpád: Az új rendszerủ logisztikai tisztképzés - valóban „eltünt” a szakma? Hadmérnök, 10 (2015/1). 49-61.

5. Turcsányi Károly: A haditechnikai eszközök megbízhatóságának elméleti alapkérdései. Egyetemi jegyzet. Zrínyi Miklós Nemzetvédelmi Egyetem, Budapest, 1999.

6. Turcsányi Károly: A haditechnikai biztosítás alapjai I. Jegyzet. Zrínyi Miklós Katonai Akadémia, Budapest, 1995.

7. Ungvár Gyula: A haditechnikai fejlesztés-korszerüsítés (FEKOR) filozófiája és stratégiája. Egyetemi jegyzet. Zrínyi Miklós Nemzetvédelmi Egyetem, Katonai Műszaki Doktori Iskola, Budapest, 2004. 